\title{
Vygotsky's theories of play, imagination and creativity in current practice: Gunilla Lindqvist's "creative pedagogy of play" in U. S. kindergartens and Swedish Reggio-Emilia inspired preschools
}

\author{
Monica Nilsson* \\ Beth Ferholt**
}

\begin{abstract}
The ideal of modern western childhood, with its emphasis on the innocence and malleability of children, has combined with various social conditions to promote adult's direction of children's play towards adult-determined developmental goals, and adult's protection of children's play from adults. However, new forms of play, in which adults actively enter into the fantasy play of young children as a means of promoting the development and quality of life of both adults and children, have recently emerged in several countries (Sweden, Serbia (the former Yugoslavia), Finland, Japan and the United States). In this paper we discuss the theoretical support for this new form of activity: we argue that Gunilla Lindqvist's reinterpretation of Vygotsky's theory of play, with its emphasis on the creative quality of play, is unique amongst contemporary Western European and American theories of play. And we describe a series of formative interventions that are both instantiations of this new form of activity and an investigation of its theoretical support, which are being conducted in the United States and Sweden. Researchers at the Laboratory of Comparative Human Cognition at the University of California, San Diego have implemented and studied Lindqvist's creative pedagogy of play in U.S. early childhood public school classrooms. Over the past year the central component of this pedagogy, playworlds, has been introduced and studied in three Swedish Reggio-Emilia inspired preschools. In conclusion, some of the findings from these research projects are presented.
\end{abstract}

Keywords: Cultural-Historical Theory. Play. Early childhood education.

* Professor of School of Education and Communication, Jönköping University, Sweden.

** Teacher of Department of Early Childhood and Art Education, Brooklyn College, City University of New York. 


\section{Introduction}

The ideal of modern western childhood, with its emphasis on the innocence and malleability of children (ARIES, 1962; FASS, 2007), has combined with various social conditions to promote two categories of play. However, new forms of play that have recently emerged in several countries (Sweden, Serbia (the former Yugoslavia), Finland, Japan and the United States), and that are commonly called playworlds (LINDQVIST, 1995), do not fall into either of the categories. In playworlds adults do not direct children's play towards adult-determined developmental goals. Nor do adults in playworlds protect children's play from adult interference. Instead, in playworlds adults actively enter into the fantasy play of young children as a means of promoting the development and quality of life of both adults and children (FERHOLT, 2010, MARJANOVIC-SHANE et al., 2011).

In this paper we discuss theoretical support for the playworlds activity. We argue that Gunilla Lindqvist's (1995, 2001a, 2003) reinterpretation of L. S. Vygotsky's theory of play, with its emphasis on the creative quality of play, is unique amongst contemporary Western European and American theories of play. And we describe a series of formative interventions (ENGESTRÖM, 2008) that are both instantiations of this new form of activity and an investigation of its theoretical support, and which are being conducted in the United States and Sweden. Some of the findings from these research projects are presented in the paper's conclusion.

\section{A new form of play}

Aries's Centuries of Childhood (1962) has been incorrectly interpreted to assert that childhood is a modern western invention, not in existence outside the west or before the late sixteenth century. However, it has been convincingly argued that various intellectual forces of the Enlightenment, such as those descriptions of children and childhood presented by Jean-Jaques Rousseau and John Locke, with their influence on political discourse, eventually combined with myriad other social forces to create a modern western childhood defined and maintained by a newly refined age consciousness (FASS, 2007; WOLFF, 1998).

We can assume that the ways that adults have engaged, or failed to engaged, with children's play must have been shaped by such changes. Perhaps there has been a condition in which children's play is sometimes integrated with adult activities, and sometimes conducted apart from adults, but is neither directed, protected or jointly created and exploited by adults; a condition in which children's play is isolated from adult activities, and then either directed towards adult-determined developmental 
goals or protected from adult interference; and a third condition in which children and adults engage in adult-child joint play for the purpose of promoting the development and quality of life of both adults and children. This is not an argument in support of chronological or genealogical movement, or in support of a narrative of enlightenment or progress. Rather, this hypothesis supports the claim that models of play are socially and historically determined, that these models operate conceptually in ideas of childhood and empirically in the classroom, and that certain of these models of play have dominated our thinking of play at certain places and at certain times.

The play of modern western children often takes place in settings which isolate children and childhood activities from adults and adult activities: in pre-schools, schools and after-school programs; in play-rooms and on play-grounds and playing fields; on television and computer monitors; and in the offices of child therapists. These settings are carefully designed and supervised by adults whose goal is, usually, to shelter or direct this play so that children further their social, cognitive or psychological development towards adulthood. These children do find time and space to play outside of these settings, on their own and away from adult protection and supervision, and also with adults for mutual benefits, but these occurrences are haphazard and rare.

However, in Finland, Sweden, Serbia, Japan and the United States (MARJANOVIC-SHANE et al., 2011), play settings are being systematically constructed to promote playworlds, which differ significantly from the modern western model of play. All of these playworlds were independently inspired by Vygotsky's theories of play and art and creativity, as well as by a variety of other theories of play, art and creativity, and by local practices. In Sweden and the U.S. playworlds have been inspired by the play in Pentti Hakkarainen's laboratory, Silmu, in Kajaani, Finland (HAKKARAINEN, 2004), and, as we will discuss below, by Gunilla Lindqvist's (1995) studies of playworlds.

Instantiations of these playworlds differ across these five countries. A folk tale or classic work of children's literature is often used as a key organizing artifact in playworlds, and dramatic enactments are often used to merge play with the artistic and scientific topics, theories and media that the adults bring to the playworld. However, playworlds can take place in and out of schools. Adult participants can be teachers, teachers in training, researchers, and/or professional visual artists, actors and musicians. And child participants can be any age.

\section{Theoretical support for this new form of play}

Along with this posited shift in play practice, there has been a parallel shift in psychological theories of play. In contemporary Western European and American 
biological, psychoanalytic, cognitive-developmental and cross-cultural psychological theories of play we find the assertions that children's play is in no way fundamentally similar to adult activities, and that adult knowledge, experience or developmental stage is a teleology for children's play. However, Lindqvist (1995, 2001a, 2003), the designer of the first playworlds in Sweden (and the author who coined the term 'playworlds'), reinterprets Vygotsky's $(1978,1987,2004)$ theory of play to argue that children's play is an early form of the artistic and scientific endeavors of adulthood, and, therefore, produces new and intrinsically valuable insights - insights which can be of value to adults and children alike. Lindqvist's theory of play (1995, 2001a, 2003) does not share with contemporary Western European and American theories of play (theories of K. Groos, E. L. Baldwin, S. Freud, A. Freud, M. Klein, E. H. Erikson, D. W. Winnicott, J. Piaget, G. Fein etc.) the inclination to describe adult knowledge, experience or developmental stage as a teleology for children's play.

For instance, Groos and Baldwin (1901), one of the most influential modern western play theorists, presents a biogenetic theory of play in his famous book, The Play of Man. In his account play is the body's way, not of engaging in, but of preparing itself for, the tasks of adult life. In play children are practicing for adulthood by developing the physical and intellectual skills necessary for their future functioning as adults. And the psychoanalytic play theorists - A. Freud (1964), Klein (1986), Erikson (1963), Winnicott (1971) etc. - base their work in S. Freud's (1950) assertion that imagination is a form of consciousness present from the outset in the child, and that the child moves from a life in a fantasy world to a life in a real world (so that the play of childhood is of a different world than are the activities of adulthood). These theorists argue that children's play is a path to adult mental health. Furthermore, S. Freud's theory that the child moves from life in a fantasy world to life in a real word greatly influenced Piaget's (1951) own theory of two worlds. In Piaget's (1951) theory there is first a stage of imaginative "autistic" thought, which is not directed towards the real world, and later a stage of realistic thinking, thinking in which the task is adaptation to and action on reality. For Piaget adult cognition is the teleology for child development in play (although this development is not contributed to by the play itself, but by the stage which determines the character of the play).

In contrast, Lindqvist (1995, 2001a, 2003) reinterprets Vygotsky's theory of play through his Psychology of Art (1971), and through a modified reading of "Imagination and Creativity in Childhood" (2004). She agrees with D. B. Elkonin (2005) concerning the importance of Vygotsky's $(1987,2004)$ claim that imagination and realistic thinking act as a unity in the processes of invention and creativity. But she argues that Elkonin did not sufficiently focus on Vygotsky's assertion that children's play is a creative cultural manifestation in humans. 


\section{Vygotsky's theory of play}

Vygotsky's theory of play is most well known from his chapter, "The Role of Play in Development", in Mind in Society (1978). In this work Lindqvist found support for her insistence on the importance of adult participation in children's play. Children are never alone in play, but rather adults are always a part of children's play, even when this involvement consists of creating a protected space apart for this play. Therefore, designing a play pedagogy involves deciding upon the ways that adults will join children in play, not deciding whether or not adults will enter children's play at all.

Vygotsky (1978) insists that a child's world is not solely a world of play, separate from and less real than our own world. He reminds us: "To behave in a real situation as in an illusory one is the first sign of delirium" (1978, p. 102). And he then states, bluntly: "Only theories which maintain that a child does not have to satisfy the basic requirements of life but can live in search of pleasure could possibly suggest that a child's world is a play world" (1978, p. 102).

Vygotsky (1978) also explains that play is not a prototype of everyday activity. In real life action dominates meaning, but in play action is subordinate to meaning. In real life a child's behavior is not always guided by meaning, but, instead, the child is often spontaneous. It is only in play that the child can be strictly subordinated to rules, because it is in play that subordination to rules leads to pleasure.

It is because of this difference between the child's play and everyday activity that play creates a zone of proximal development for the child. "In play a child always behaves beyond his average age, above his daily behavior; in play it is as though he were a head taller than himself" (1978, p. 102) The child is able to move forward through play because in play action is subordinated to meaning, and the child is motivated to move forward through play because in play the subordination to rules is pleasurable.

Vygotsky uses his famous example of the stick that, in play, becomes the horse, to explain how play allows children to develop a separation between perception and meaning. The stick is the "pivot" which allows thought, word meaning, to be separated from objects, and action to arise from ideas as opposed to arising from things. Although the stick is still needed to separate thought and object, the child's relation to reality is now changed because the structure of his perceptions has changed. For the first time meaning predominates over object. Vygotsky (1978, p. 98) writes: "This characterizes the transitional nature of play; it is a stage between the purely situational constraints of early childhood and adult thought, which can be totally free from real situations".

Vygotsky (1978, p. 99) described these phenomena by arguing that play is paradoxical: 
The primary paradox of play is that the child operates with an alienated meaning in a real situation. The second paradox is that in play she adopts the line of least resistance - she does what she most feels like doing because play is connected with pleasure - and at the same time she learns to follow the line of greatest resistance by subordinating herself to rules and thereby renouncing what she wants, since subjection to rules and renunciation of impulsive action constitute the path to maximum pleasure in play.

As Vygotsky's (1978, p. 86) concept of the zone of proximal development is defined as "the distance between the actual developmental level as determined by independent problem solving and the level of potential development as determined through problem solving under adult guidance or in collaboration with more capable peers", this claim of Vygotsky's (1978, p. 99), that the "essential attribute of play is a rule that has become a desire", helps us to understand how, in the zone of proximal development of play, the creation of the new is possible. In this zone a child is able to put forth the great effort, to make the stretch, to enter into dialogue with her future.

Vygotsky (1978, p. 100) states this point in these words:

Play gives a child a new form of desires. It teaches her to desire by relating her desires to a fictitious "I," to her role in the game and its rules. In this way a child's greatest achievements are possible in play, achievements that tomorrow will become her basic level of real action and morality.

This tomorrow is an endpoint for play, but a moving endpoint, and an unknown.

Support for Lindqvist's claim that children's play is a creative cultural manifestation in humans can be found in Vygotsky's (2004) "Imagination and Creativity in Childhood" and "Imagination and its Development in Childhood." (1987). As Lindqvist $(1995,2003)$ argues, it is in these works that Vygotsky discusses the human process of creative consciousness, the link between emotion and thought, and the role of imagination. This discussion brings to the fore the issue not only of the link between reality and imagination, but also issues of reproduction and creativity (production).

In "Imagination and Creativity in Childhood" Vygotsky (2004, p. 2) begins by defining the creative act as "(a)ny activity that gives rise to something new". To hone this definition he makes a distinction between "reproductive" activity, in which 
"nothing new is created," but, instead, there is "a repetition of something that already exists" (VYGOTSKY, 2004, p. 2), and a "combinatorial or creative activity" in which one is "not merely recovering the traces of stimulation that reached my brain in the past" (VYGOTSKY, 2004, p. 3). In creative activity, Vygotsky (2004, p. 4).writes: "I never actually saw this remote past, or this future; however, I still have my own idea, image, or picture of what they were or will be like".

This basic distinction is what allows anyone who is engaged in creative activity, including children, to produce something novel:

If human activity were limited to reproduction of the old, then the human being would be a creature oriented only to the past and would only be able to adapt to the future to the extent that it reproduced the past. It is precisely human creative activity that makes the human being a creature oriented toward the future, creating the future and thus altering his own present. (VYGOTSKY, 2004, p. 3).

The creative activity that Vygotsky is discussing is imagination. He writes that imagination is an important component of all aspects of cultural life, essential to the artist and the scientist alike. "(A)bsolutely everything around us that was created by the hand of man, the entire world of human culture, as distinct from the world of nature, all this is the product of human imagination and of creation based on this imagination" (VYGOTSKY, 2004, p. 4). Vygotsky (2004, p. 5) quotes T. Ribot, writing that all human-made objects, every one, can be called "crystallized imagination". Vygotsky is describing the role of imagination in the production of artifacts, as defined by culturalhistorical activity theory: those aspect of the material world that have been modified over the history of their incorporation into goal directed human action (ILYENKOV, 1977).

Vygotsky is arguing that imagination is an essential aspect of all thought. As M. Cole (COLE; PELAPRAT, 2011) explains, human conscious experience is a process, a process which requires not just our phylogenetically constrained abilities and our culturally organized experience, but also our active reconciliation or "filling-in", our imagining, as we try to make sense of our world. Cole notes that the Russian word normally translated as imagination, voobrazzhenie, is made of three roots. The translation of the word according to these three roots is into-image-making. Therefore, in the language in which Vygotsky was thinking and writing, within the word imagination were the concept that all representation is in part the result of an active processing by an individual, and also the concept that it is imagination that allows us to 
move "into" this process. When Vygotsky (2004, p. 3)describes "the human being (as) a creature oriented toward the future, creating the future and thus altering his own present", when he asserts that imagination is essential to both the artist and the scientist, he is moving towards an even broader claim, the claim that we can think because we can imagine.

Vygotsky (2004, p. 33) explicitly argues that all humans, including children, are creative:

There is a widespread opinion that creativity is the province of a select few [...] This is not true. If we understand creativity in its true psychological sense as the creation of something new, then this implies that creation is the province of everyone to one degree or another; that it is a normal and constant companion in childhood.

It is not only those at the height of their creative abilities who can produce something of worth to many others of all ages, meaning that even a child in play might inspire an adult. Vygotsky (2004, p. 6) concludes: "If we understand creativity in this way, it is easy to see that the creative processes are already fully manifest in earliest childhood". Furthermore, he writes: "We can identify creative processes in children at the very earliest ages, especially in their play...all these children at play represent examples of the most authentic, truest creativity." (VYGOTSKY, 2004, p. 6).

Vygotsky continues by arguing that there is no strict line between fantasy and reality. A child at play is creatively reworking impressions he has acquired, combining them to construct a reality that meets his needs and desires. "It is this ability to combine elements to produce a structure, to combine the old in new ways that is the basis of creativity" (VYGOTSKY, 2004, p. 7).

In regards to the question of how a child's imagination differs from an adult's, Vygotsky argues against those who claim that fantasy is richer and more diverse in childhood than adulthood. He writes that the theory behind such claims mistake the undemanding and tolerant quality of child fantasy, the fact that children can indeed make anything out of anything, for richness of imagination. These theories also mistake the fact that the products of children's fantasy are obviously very different from adult reality as support for the idea that children live more in the world of imagination that in the real world. And children's interest in fantasy stories and in distortion, particularly exaggeration is another fact mistaken as support for this idea.

Vygotsky argues that children's experience is poorer than adults', that their interests are simpler, more elementary, and so also poorer that adults', and that 
children's relationship to the environment is not as complex, subtle or diverse as that of adults. Therefore, "( $\mathrm{t}$ )he child can imagine vastly less than the adult" (VYGOTSKY, 2004, p. 29). Those who conclude otherwise are using the term imagination to refer to all that is unreal, that this how they come to their incorrect conclusions. The child "has greater faith in the products of his imagination and controls them less, and thus imagination, in the everyday, vulgar sense of this word, that is, what is unreal and made up, is of course greater in the child than in the adult" (VYGOTSKY, 2004, p. 29). In truth the child's imagination it only equal to the adult's with regard to the elements used for the construction of imagination, reality, and the emotional roots of imagination. Children and adults both engage in the process of imagination, but at different levels.

In "Imagination and its Development in Childhood" (1987) Vygotsky elaborates upon his arguments in "Imagination and Creativity in Childhood" (2004). He argues that there is a complex relationship between realistic thinking and activity of advanced forms of imagination. And he concludes: "In sum, the apparent, metaphysical, and primal opposition that has been established between realistic and autistic ${ }^{1}$ thinking is both fictive and false. The differences between realistic and autistic thinking are not absolute but relative" (VYGOTSKY, 1987, p. 348).

Vygotsky (1987) claims in this chapter that imagination is an integral aspect of realistic thinking. The two are interdependent. And in the observation of imagination linked with creativity, which is imagination directed towards reality, there is no boundary between realistic thinking and imagination. This is so because "no accurate cognition of reality is possible without a certain element of imagination, a certain flight from the immediate, concrete, solitary impressions in which this reality is presented in the elementary acts of consciousness" (VYGOTSKY, 1987, p. 348). Invention and artistic creativity require realistic thinking and imagination. In these processes: "The two act as a unity" (VYGOTSKY, 1987, p. 349).

The above is the central thrust of Vygotsky's argument in "Imagination and its Development in Childhood" (1987). Lindqvist also points out that Vygotsky stresses the fact that imagination faces forward, that those who imagine are capable of producing the new. Vygotsky (1987, p. 339) writes:

The essential feature that distinguishes imagination from other forms of mental activity is that it does not repeat combinations of accumulated impressions but builds a new series of impressions from them. The very foundation of the activity that we refer to as imagination is the introduction of something new into the flow of our impressions, the transformation of 
these impressions such that something new, an image that did not previously exist, emerges.

Vygotsky explains that earlier theories of psychology were not able to understand imagination because they considered all forms of human mental activity to be associative combinations of accumulated impressions, and therefore had to attribute imagination to other functions. However, imagination does what other functions cannot do: it creates the new. According to Vygotsky associative psychology reduced imagination to memory. While idealist psychology tried to show that memory is just a special form of imagination, as perception is a form of imagination that constructs our perception of reality. The idealist psychologists argued that creative imagination is inherent in consciousness, that consciousness creates a priori forms, and that these forms produce all our impressions of external reality.

\section{Lindquist's theory of play}

Elkonin was a student of Vygotsky's who summarized his teacher's work on play in his book, "Psychology of Play" (2005), published in Russian in 1978. Elkonin's (2005) main argument is that Soviet psychology crystallized an approach in which play is described as an activity performed by the child that embodies the child's relationship to the external world and to social reality. Vygotsky's $(1987,2004)$ claim is a rebuttal to those theories of play that position imagination and realistic thinking in opposition to one another. Elkonin (2005) states that the play theory of Vygotsky and his students, through the realization that imagination and realistic thinking act as a unity in the processes of invention and creativity, overcomes the naturalistic and psychoanalytic theories of children's play ${ }^{2}$. As stated above, Lindqvist (1995, 2001a, 2003) agrees with Elkonin concerning the importance of Vygotsky's $(1987,2004)$ claim that imagination and realistic thinking act as a unity in the processes of invention and creativity, but argues that Elkonin did not sufficiently focus on Vygotsky's assertion that children's play is a creative cultural manifestation in humans ${ }^{3}$.

Lindqvist (1995, 2001a, 2003) argues that in "Imagination and Creativity in Childhood" Vygotsky (2004) links his ideas about art to his theory of play. Here he describes the imaginary process as creative interpretation and play as an early basis for children's creativity. Therefore Lindqvist also turns to Vygotsky's theory of art (1971), as she reinterprets Vygotsky's work and develops her own theory of play.

Lindqvist (1995, 2001a, 2003) argues that Vygotsky starts from the study of art and literature in his efforts to describe the cultural development of humans. He is interested in the dynamic links between human consciousness as it is reflected in 
children's play and the cultural, aesthetic forms of drama and literature. Like Elkonin (2005), and also A. N. Leontiev (1981), Lindqvist (1995) argues against the view that children's natural development is separate from the culture which surrounds them, or that play expresses the child's natural development and is therefore free from adult influence. She, too, contrasts her approach with both a psychoanalytic and a cognitive approach to children's play, writing that in the psychoanalytic approach the child processes inner conflicts through play, in the cognitive approach the child builds knowledge through play, but that in both cases, unlike in her play pedagogy, the child is left alone with, and in, play.

For Lindqvist (1995, p. 16) it is essential that we remember that Vygotsky's theory of play "is an all-embracing cultural theory, which combines emotion and thought, aesthetics and rationality". She argues that for Vygotsky it is the exaggerations of imagination that give science the ability to recognize the new. Emotions and imagination are in a dialectic relationship, as the images of our imagination provide our emotions with an internal language, and emotions influence our imagination. Therefore, emotion and thought are related. Also, for Vygotsky, it is the exaggerations of imagination that give art the ability to recognize the new. And there is a dialectic relationship between imagination and reality, considered to be accessible by the rational. Imagination develops creativity because it is an emotional and intellectual process that takes fragments of reality and transforms them. These newly made fragments re-enter reality.

In Lindqvist's (2003) view the way that Vygotsky links the emotions to thought gives aesthetics a new role in the process of consciousness. According to her, Leontiev and Elkonin ignore the fact that in Vygotsky's theory of play, consciousness is the key concept and the principle of individual development, that play is the activity through which children become conscious of the world. Also, Lindqvist (1995, p. 40) writes: "Play does not keep emotion, thought and will separated from one another". By contrast, emotions are not emphasized in Leontiev and Elkonin's interpretations of Vygotsky's theory of play.

Lindqvist (1995, p. 40) argues that Vygotsky's emphasis on dialectics between the world of adults and children makes consideration of the dialogic process of central importance:

(D)ialogue with other human beings keeps man (the subject) in a dynamic relationship to his environment (the object), and he develops his conceptions of the world through a process which is both reproductive and 
productive. At the same time as he can remember and repeat patterns of behavior, he is able to shape and reshape his own conceptions of the world, i.e. he makes his own interpretations. This is a dialectic theory of influence in the pedagogic process.

Of central importance to Lindqvist's (1995, p. 50) theory of play is her positioning of herself in opposition to Leontiev, whom she characterizes as believing that adult roles are what children play at, as believing that children's "play faces the future" because children in play are modeling themselves on adults. She explains that Leontiev thinks of play as reproduction of roles in an adult world, not as productive. Here Lindqvist is arguing that children are, often, modeling themselves on adults in play, but that play faces a future that will be created, in part, by those who are now children, and that will be created within some constraints that those who are now adults cannot even imagine.

Lindqvist's contribution to play theory derives in part from her ability to interpret Vygotsky's work from outside the cultural, historical and political context in which it was created. Leontiev's belief that adult roles are what children play at also parallels what Lindqvist (1995) characterizes as a Soviet emphasis on a harmonious relationship between adults and children. According to Lindqvist, this emphasis has lead to adults entering children's play to correct the play, instead of letting children act out their fears. Lindqvist (1995) argues that for Leontiev, play is interpreted as a realistic phenomenon, and therefore there is no conflict between reality and the children's interpretations in play. In contrast, according to Lindqvist, Vygotsky sees play "as a way for children of expressing their feelings and asserting themselves in relation to adults", but "at the same time, he senses a longing on the part of the children to move closer to the adult world" (LINDQVIST, 1995, p. 50). For Lindqvist (1995) this vision of play is neither dualistic nor harmonious, but is dialectic, and allows adults to enter children's play without stifling children's expression of their fears.

\section{Lindqvist's creative pedagogy of play}

Lindqvist states that a significant result of Elkonin's oversight, his insufficient focus on Vygotsky's assertion that children's play is a creative cultural manifestation in humans, was that Elkonin's work promoted adult intervention in children's play that stifles the creative potential of children's play, rather than a creative approach to children's play, which fosters this potential. Therefore, she reinterprets Vygotsky's theory of play with the expressed purpose of designing, implementing and studying a 
pedagogy in which adults assume a creative approach to children's play. B. SuttonSmith (1997, p. 50) writes in The Ambiguity of Play that "[...] extrinsic academic, social, moral, physical, and cognitive play functions, with a progress-oriented thrust, have been the major focus of most child play scientists [...]". Lindqvist's (1995) "creative pedagogy of play" permits the study of play and culture in preschools, the study of the aesthetics of children's play, and also the study of play as an activity in which children produce results that draw upon, but do not mimic adult achievements in any of the categories listed above. Lindqvist's creative pedagogy of play promotes the study of joint adult-child play in which children's ability to produce results in play that are novel to both adults and children is a central feature.

In Lindqvist's (1995, p. 72) creative pedagogy of play interaction between adults and children is structured around a piece of literature, or another work of art. The adults and children work together to "bring the literature to life" through drama (or, in some cases, dance - although we will here discuss the dramatic playworlds). They assume roles, characters from the literary piece, and "make use of the intrinsic dynamism between world, action and character in drama and play" (LINDQVIST, 1995, p. 72). Concretely, through joint scripted and improvisational acting and set design the children and adults transform their classroom into a world inspired by a book (and, in the process, the book they are working from into a world inspired by their activity). Lindqvist gives rich and concrete examples in her publications (1989, 1992, 1995, 1996, 2000, 2001a, 2001b, 2002) of implementations of her creative pedagogy of play.

Lindqvist's (1995)pedagogy is designed to investigate how aesthetic activities can influence children's play, and the nature of the connections between play and the aesthetic forms of drama and literature. She is trying to find a "common denominator" of play and aesthetic forms, a denominator which she calls "the aesthetics of play". Lindqvist (1995) considers one of the most important conclusions of her investigation to be that the development of adult-child joint play is made possible through the creation of a common fiction, which she calls a "playword". The playworld is created through the activity of bringing the actions and characters in literary texts to life through drama. It is the interactive space in which both children and adults are creatively engaged.

Of adults' creative approach to children's play in her creative pedagogy of play Lindqvist writes the following (italics are ours):

During the course of the theme, I have seen the teachers become someone in the eyes of the children. They have turned into interesting and exciting people. I have often had the feeling that staff members at a day-care center are perceived as 
rather anonymous grown-ups. Sometimes, the children will not even notice if a teacher is ill and has been replaced. In a way, assuming roles has liberated the adults - it has enabled them to step out of their "teacher roles" and leave behind the institutional language which is part of the teacher role in preschools and schools. By virtue of the fictitious role, the teachers have dared to try new attitudes and ways of acting. (LINDQVIST, 1995, p. 210-211).

The children like playing with the adults. When adults act out roles, the children know they are playing and do not have to worry about 'adult conventions'. The adults show the children that they know how to play - that is to say, that they are aware of the rules of play. (LINDQVIST, 2001a, p. 12).

The children have often been longing to meet the different dramatized characters or personalities. The play settings which have been established have inspired them to play, but the playworld would not have come alive if it had not been for the physical presence of the living, breathing characters (played by the adults). (LINDQVIST, 1995, p. 211).

\section{Formative Interventions}

As a scholar of Vygotsky's work, Lindqvist fully appreciated that the confrontation of theory with practice is a powerful source of theoretical development. Lindqvist $(1995,2001 \mathrm{a}, 2003)$ designed and implemented her creative pedagogy of play to further her reinterpretation of Vygotsky's $(1987,2004)$ theory of play. Researchers at the Laboratory of Comparative Human Cognition at the University of California, San Diego and in Sweden have continued this endeavor. Along with several other researchers, we, the authors, have implemented and studied the playworld activity, and, although Lindqvist did not use this term, both our work and Lindqvist's can be described as "formative interventions" (ENGESTRÖM, 2008).

Y. Engeström argues (2008) that Vytgotsky's methodological principle of double stimulation leads to a concept of formative interventions. He describes formative interventions by contrasting formative interventions with "the linear interventions advocated [...] by the literature on design experiments" (ENGESTRÖM, 2008, p. 15) - Engeström (1992, p. 141) refers to the work of Cobb et al. (2003) and Collins, Joseph and Bielaczyc (2004) when discussing design experiments. Brown (1992) describes design experiments as "engineering innovative [...] environments and simultaneously conducting experimental studies of those innovations". Engeström (2008, p. 15-16)states that the crucial differences between the two are as follows: "In 
formative interventions, the subjects (whether children or adult practitioners) construct a novel solution or novel concept the contents of which are not known ahead of time to the researchers"; "In formative interventions, the contents and course of the intervention are subject to negotiation and the shape of the intervention is eventually up to the subjects"; and, "(i)n formative interventions, the aim is to generate intermediate concepts and solutions that can be used in other settings as tools in the design on locally appropriate new solutions".

Our ethnographic data in the formative interventions that will be described below include detailed field notes of every site visit. Field notes are written by participating researchers and, at times in the U.S., by an external observer. The teachers also write (and, in the U.S., audio-video record) notes, themselves.

In addition to these notes, ethnographic data in these formative interventions include audio and audio-video footage of classroom activities related to the playworld projects. At times one of the researchers videotapes using a hand-held camera and a second camera records from its position on a tripod, or more than one video camera may be passed between all of the researchers. At times the children also videotape the proceedings. In Sweden we have begun to record small sports cameras that are strapped to teachers' and children's chests. And we have professional filmmakers and photographers come to the site and document the playworlds. We also use a video camera or an audio recording device to record adult rehearsals, adult planning meetings and individual interviews with adult and child participants.

Lastly, in the US playworld described below we have draw on email correspondence among the adult participants that are written over the course of the projects. Some of these emails contain logistical arrangements, others contain playworld-related discussion of educational theory, literature, philosophy and theology, and others contain discussion of the developing acting skills and identities of the adult participants. These emails provide additional insight into the adults' experiences in the playworld.

\section{A Description of an instantiation of the creative pedagogy of play in the United States}

As was to be expected, transporting Lindqvist's creative pedagogy of play from Sweden to the United States required us to change and develop this pedagogy. Lindqvist implemented her pedagogy in preschools, and the Swedish preschool has a reputation for being progressive and child centered. The Swedish childcare system is public and municipalities are obliged to provide childcare. Preschools provide care for children 
aged $1-6$ years of age. In the U.S., many public elementary schools now include children as young as four years of age.

As a pilot study confirmed, teachers of young children in the U.S. are often reluctant to address topics that raised negative emotions, such as fear or sadness, with their students. They are also commonly resistant to disorganization or "mess," and loud sounds or "noise," in their classrooms. After much searching we were able to find a teacher with the freedom and inclination to both address these topics with his students and allow his classroom to be "messy" and "noisy." However, and not incidentally, this teacher worked in an unusual setting and in an unusual capacity for a U.S. teacher. He is a visual artist with a professional interest in the relation between art creation and emotion, and he works in a public elementary school on a large military base. Furthermore, during this playworld project the U.S. was deeply entrenched in a war with Iraq.

The above factors led to U.S. playworlds that were particularly emotionally charged, and which were infused with rich visual art. Another difference between Lindqvist's Swedish implementation of her pedagogy and playworlds in the U.S. is that teachers in public elementary schools in the U.S. often work on their own, and with little preparation time allowed in their schedules. In response to this difference between the two countries' early childhood educational systems, playworld researchers have joined the teachers as fellow actors in several of the playworlds that have been created in the U.S. to date. As participant-observers we researchers gained some perspectives that have proved essential to our study of emotion, imagination and creativity (FERHOLT, 2010).

In this U.S. playworld the class with which we worked was a kindergarten and first grade class of 20 students. The playworld was based on C. S. Lewis's (1950) The Lion, the Witch and the Wardrobe. The first half of this novel was read aloud to the children before the acting began but the second half of the novel was never read to the children. Instead the children became more and more active participants, throughout the course of the project, until they collectively wrote and directed their own resolution to the novel's central conflicts.

Over the one-year period during which the playworld took place there were 14 playworld sessions in which some or all of the participants acted. These playworld sessions occurred on Friday afternoons and lasted approximately 2 hours. Most of these sessions included reflection upon the enactments in the form of discussion and then free play or art activities.

Most of these 14 sessions included all four researchers, who played the child heroes of the playworld. The teacher joined during the seventh of these sessions, playing 
the evil White Witch, and the children joined during the eighth of these sessions, as themselves. For the final of these sessions the children were the primary planners of the adult-child joint play.

All of these playworld sessions involved set pieces and props created by both the adults and children, including some props that were designed to appeal to the participants' senses of touch, smell and sound. By the time that half of these sessions were completed the teacher, who had been moving the set pieces to the side of the classroom at the end of each playworld session, began to leave the set pieces in place throughout the week. The classroom was filled with the large, colorful structures, and the teacher conducted all of his classroom activities in and around a cardboard dam, cave, castle etc.

This playworld generated a tremendous amount of data, in part because four primary and four secondary researchers were involved in the project and writing copious filed notes. Hundreds of hours of video footage were also collected. The following is, therefore, a narrative summary of the playworld produced from extensive analysis of all of the forms of ethnographic data collected ${ }^{4}$.

On the first day of school the children found a locked wardrobe in their classroom, whose origin no one appeared to know. A few months later their teacher, $\mathrm{Mr}$. Michael, was not able to read the next chapter of The Lion, the Witch and the Wardrobe aloud because, as he told the children, "The words in the book have disappeared!". To the sound of rain, the researchers came into the classroom playing the child heroes of the book: Susan, Peter, Edwina and Lucas.

On Fridays we researchers came to the classroom from our university and performed another scene from Lewis's novel. On Mondays the children found a few of the words from the book, words concerning the imaginary world of Narnia, on the floor of their classroom - 'trees', 'cave', 'beaver dam', 'castle', 'table', 'sewing machine, 'cage' - and created this set piece or prop out of cardboard and paint over the course of the week. As the weeks went by the classroom became covered in the colorful, delicatelywrought trappings of the world of Narnia, until, eventually, the teacher stopped moving the cardboard structures for his literacy and math groups, and, instead, moved the literacy and math groups into Narnia - He was supported in this choice in part by the children appearing to be more fluent readers when they were sitting in the wardrobe.

As the Friday session came and went the back came off the wardrobe. The ice in Narnia was real, and really cold on bare feet, just as the eggs and tea we all shared at cave of the faun, Mr. Tumnus, were really filling. And the often asked question, "Who is the White Witch?" was answered when the children's teacher entered the play in a white fur 
coat and long white gloves. Then the children became visible to the adult actors and entered the story as story designers. The children began to stay in from recess and after school to sit in the White Witch's castle and recount the dreams they'd had the night before about Narnia and their classroom, or to draw pictures in which they saved members of their family who had died, or were deployed in Iraq, from the White Witch, or simply to spend a few extra minutes sitting on the floor of the wardrobe amongst the soft fur coats. And, finally, Mr. Tumnus was saved from the White Witch, breathed on until he turned from stone back to living faun, the children's boisterous chanting: "Party! Party! Party!" filled the room, and we all joined the inhabitants of Narnia for a giant feast.

When our playworld was completed the children we had worked with needed to represent the playworld to their families in such a way that they would be able to take these school experiences home with them for the summer. Like the researchers in the project, returning to the laboratory at the university, the children were faced with the task of representing the playword both to themselves and to outsiders. All participants, adults and children, needed to contain their experience of the playworld for transport, to carry these experiences to a new time and place, and then to revive these experiences in such a way that they would be comprehensible to a new audience, and, also, despite the passage of time and process of translation from medium to medium, still recognizable to themselves.

In order to make their experiences of the playworld comprehensible to their families, and hence to their future selves, the children came up with the wonderful plan of staging a play about the playworld for their families. In an effort to stay true to their memories, not to reenter the playworld but to revive its form with a temporary 'breath of life', the children designed, after much debate, a production that was avant-garde and unexpected, and that succeeded in maintaining and conveying the creative integrity of the playworld. In the children's play about the playworld a wooden prop was reproduced in cardboard, and this replica was erected next to its wooden counterpart for use in the play, while other props from the playworld were used to represent themselves in the play. Some of the carefully and lovingly created costumes from the playworld were replaced by paper symbols of these costumes, while others were used as costumes in the play. Some of the lines in the play were taken from the playworld, while others were new creations. Some of the children played themselves, and others played characters that had been played, in the playworld, by adults. Some of the children stayed in one character for the whole play, and others played a new character every scene - meaning that in most scenes there were multiple actors playing each of the characters. 


\section{A Description of a current Swedish instantiation of the creative pedagogy of play}

Unlike Linqvist's work, the following current instantiation of the creative pedagogy of play took place within a Swedish preschool, which is one of three related preschools that practice a pedagogy called exploratory learning. Exploratory learning is a pedagogy inspired by the Reggio Emilia pedagogy of the Northern Italy. Loris Malaguzzi is the person most famously associated with this pedagogy and significant concepts include: pedagogical documentation, which is a tool and an approach which makes visible children's interests, questions and hypothesis about phenomenon and relationships in the world; and the organization of pedagogical work in the preschool into yearlong exploratory projects. The hundred languages is a metaphor used within exploratory learning to convey the idea that children approach the world and express themselves not only through spoken and written language but also through their bodies and five senses and, therefore, through art forms of all kinds: music, dance, painting etc.

Play or playworlds was the annual theme of these three related preschools when the following project took place, although it was up to each teacher team to decide on the content of their particular project. In one of the two and three year old classrooms at least one of the teachers, Anna-Karin, was already particularly interested in play and already playing with the children. The authors of this paper, "playworld researchers," were invited to consult during the previous spring semester, when the preschools were not yet in their play-themed year, and at this time we encouraged the teachers in this classroom to play with the children while these teachers were in role. In the spring we primarily supported teacher-in-role play that was already happening in the classroom and discussed the teachers' commitment to not imposing a prewritten and adult-written story that might override the children's interests. The playworld itself took place at the beginning of the school year, the following fall, and is still in progress as we write this paper.

The teachers at these preschools, due to their practice of exploratory learning, spend a great deal of time and energy producing pedagogical documentation. The following description of this playworld consists, therefore, in great part of carefully selected portions of teacher reflection that the teachers have recoded/created, themselves. We have found that in many playworlds teachers' words are a most valuable form of data/analysis (and having a huge database of teacher reflection changes researcher relation to the playworld in ways that we are just beginning to explore).

This playworld began in true after the spring play and the summer break, when one of the teachers, Elin, decided that she would go into role in her play with the 
children. Elin was not the teacher who considered herself to be an expert player with the children. Elin's play with the children in the spring and before the spring had predominantly resembled theater more than it resembled play.

Elin chose to be a princess from a series of books, one of which was very popular with the children. In this particular book a princess is not scared of a noise in the dark but gets out of bed with her sword to investigate and finds a basement troll, whom she eventual puts to sleep with the help of her newfound friends. Anna-Karin first read the book aloud to the class. Then, the following week, Elin appeared outside the preschool window unexpectedly one morning as the princess. After she acted by herself for a while the children just as unexpectedly put on their boots on their own, ran outside and joined her. The princess was wearing a wonderful costume that she had made herself and which included a golden crown, she had with her a large suitcase with a golden crown emblem on its side, and she carried a sword.

Elin wrote a reflection note in the pedagogical documentation stating that this process was fun but that she did not get the playing experience/feeling where reality disappears:

I felt like I was playing and the kids were curious about what I was playing, but not as if it was a common play in which they participated fully. They participated but based on what I said and how I acted. More like a play in which they had to step into the scene and participate than a playworld where anything is possible and they can influence the play.

When the play ran out we moved into either a new play or another activity.

Several adjustments were then made, including having another teacher on hand to take care of non-play issues and limiting the number children with whom Elin was playing. Several events took place in which the children were shown and manipulated and responded to documentation of their own play. Eventually something that looked more like the adult-child joint play of a playworld emerged.

The following description is from a reflection on this play in the teachers' pedagogical documentation:

There are several parallel plays with frogs, humming and (two children) playing grandmother and child. But all agree that it is wet and they need boots. The boots and the keys keep the play together. The props keep the play together even though the kids have different ideas about the play and are not constantly playing together. 
The children also painted and drew the princess and the basement troll in the atelier and built things for the play in the construction room. This both enriched their play and shows how their bodily experiences through play informed their work in other "languages." Several of the props and characters mentioned above crossed the spaces in the room/"languages". For instance, boots, water and keys were often represented and explored. The suitcase took on a life of its own, becoming a "portal" to the playworld, like the wardrobe: We believe that this had to do with the princess's convincing and moving performance of sleeping with a blanket that she took from her suitcase in her very first performance and in several subsequent performances. The children and the adults are still spending a lot of time sleeping in suitcases in this playworld, magical sleeps (that reminds the researchers in the project of Shakespeare's "A Midsummer Night's Dream").

At one point in the project the teachers felt that they needed new fuel for the play and also, perhaps, needed to challenge the children. They decided to interview the children about the characters who were present in their play. They asked the children one at the time: Where does the princess live?; Where do the princess and the basement troll play? etc. This seemed to bring new energy to the joint play and led the teachers to reflect upon the children's play competences, thus:

Ability to work/play many together. To hang in, playing for a long time and adding new ideas to hold their own and others' interested. Found a way to get into play, for example, by bringing a dog, say you bleed, sleep or invite to a party. When the play can be developed, the children receive new experiences 5 and thoughts that they take with them into the next play occasion. Likewise, the play influences the children's expressions in the atelier. Lessons from different occasions enrich each other. What we played we take with us into the studio and then with new ideas and experiences go into the play again.

The teachers related the creative activity of adult-child joint play to exploratory learning in this way. And they wrote that something about the relationship between learning and play can be found in the meeting of exploratory learning and playworlds:

Skill and ability: "This can be understood as a non-linear way of thinking in which children's learning takes new paths and takes place interlaced with the outside world, like a loop spirit rhizome" [...]. (SKOLVERKET, 2012, p. 27). 
Familiarity: The play has evolved but the children have had a shared attitude and the confidence that they had a common framework. To begin the play with everyone putting on boots, or picking up your suitcase, has created a code and community. We have become close to the children in a new way. We are invited, empowered and equal in play.

Fantasy: Truths / facts meets fantasy in play in an elated and liberating way.

This "code and community" that began in the first half of the school year carried over to the second half of the year, after the month of Christmas holiday activities and the break from preschool. In fact, the return to the playworld after the hiatus brought renewed energy and interesting changes to the playworld. In January, sharks were introduced into the playworld. The teachers explain that this is an extension of the princess play with the children, and that the few children who did not really find roles in the princess play did find their roles in the shark play.

The teachers wrote of this change in the playworld in the new year:

The children have continued to work with sharks and water. Their interest in the sharks has resulted in many many painted sharks and water. It is fun to see how the children's interest is driving the work forward. The children themselves have guided what they want to do that this is the result of where we ended up last week. We talk about water, maps, pirates and the swimming school. Their conversations and experiences run what they play and paint. It is fun to see how interests spread and how they learn from each other. We have copied their sharks and we have them in the building room and in the light room.

In March the teachers wrote of a culminating day in this playworld, or perhaps it is a point where all agreed that the playworlds now had enough of a life of its own to shape the classroom, teachers and students anew. When Monica visited the day after this peculiarly lovely day, she noted that: "they (the teachers) were all high on the day before" (from fieldnote, March 7, 2014).

The teachers wrote the following in their pedagogical documentation:

This week we have had such a wonderful flow. We pedagogues feel that we are so happy about what we are doing and we hope that the children are feeling the same thing. We all feel the same 
wonderful feeling of getting together with the children that we did when we worked with the "Tigers' tails" (a project from a previous year). We have been drawing sharks and swimming among our drawings of the painted sharks. We have been sewing shark costume. We have been looking at fact books (scientific books) (about sharks). We have been exploring water on the light board the children have gone between activities and found their interests in the rooms they want to be in. They have been standing next to the sewing machine and watching at the same time as they have been reading in the facts books in order to choose to go into atelier and draw what they are talking about. Someone (a child) has explored water at the light board and then gone into the atelier and swum in the pictures.

Anna-Karin is recorded in the pedagogical documentation as saying that this is the best day ever. We researchers stress that she did not say that is was the day that the teachers taught the children best or most, or even that the children learned best or most on this day. The playworld has merged goals of teachers and children: This is a best day ever, not just a good day, because of something to do with happiness, flow, engagement or experience.

The teachers go on to reflect in their pedagogical documentation:

The adults have had different areas of interest based on what we see the children are interested in. When we organize ourselves in the morning and divide into different groups we can see that the day gives us more. We have a focus and the children are pushing what we are doing forward, because they can see that we are excited. We do have a structure with each group that we, the pedagogues, have an idea for and interest in what we are doing but at the same time let the children float between the groups and bring thoughts from one group to the other group. This makes the big group flow and interest grow into something big and fantastic. Often we work in different groups in each room and we used to have this idea to not disturb or be interrupted, but now we do not see one approach as more correct than the other [...] but it was fun that they went in between the activities and we believe they felt freedom and joy and that ideas and thoughts could be carried out directly.

We believe that the playworld has challenged not only a modern western divide between adulthood and childhood, and adults and children, but also commonly accepted divides within the preschool environment and structure. With these 
challenges has come openness and flow. The teachers' pedagogical documentation from which we have excerpted and presented, above, also explicitly explains that the children who have participated in this plaworld "can now accomplish things more directly, without waiting for their teachers".

\section{Conclusion}

Extensive analysis of the U.S. playworld described above has already taken place (including Baumer, Ferholt and Lecusay, 2005; Ferholt, 2009, 2010, forthcoming; Hakkarainen and Ferholt, 2013; Ferholt and Lecusay, 2010; Marjanovic-Shane et al., 2011), although the data collected in this playworld study is still generating significant findings. Because the Swedish playworld described above is in progress as we write, analysis has just begun. However, presenting finding from both projects within the same section of the paper - published finding from the U.S. playworld study and preliminary findings from the Swedish playworlds study - highlights similarities and differences between the two instantiations of Lindqvist's creative pedagogy of play. This allows for concluding speculation concerning possible current, practical ramifications of Vygotsky's theories of play, imagination and creativity.

To date and most significantly, researchers in this U.S. playworld study have found that this new form of play promotes narrative competence (BAUMER et al., 2005). We have conducted an analysis that provides evidence that expands Vygotsky's concept of the zone of proximal development so that we see not only the unidirectional development of a child towards an adult stage of development, but also the simultaneous development experienced by adults participating in the zone with the child (FERHOLT; LECUSAY, 2010). We have found that this new form of play holds special potential for making visible, and hence available for research, complex dynamic relations between such key psychological processes as cognition, emotion, creativity and imagination, and that this form of activity promotes the development of these processes in child and adult participants (FERHOLT, 2009). We have developed a unique methodology for the study of perezhivanie (roughly translatable as lived experience) through playworlds (FERHOLT, 2010). And we have studied the characteristics of perezhivanie using this playworld (FERHOLT, 2009; Ferholt, forthcoming).

The contrast between Lindqvist's work with playworlds and the U.S. playworld described above has also allowed us to isolate three conditions which we believe are essential in the creation of the shared responsibility for directing the adult-child joint play that is at the heart of Lindqvist's pedagogy. First, adults in a playworld enter fully 
into children's play by taking on play roles, putting on costumes and entering character. In doing so they are required to partially step outside of their role as teacher and to join the children in the role of fellow actor ${ }^{6}$. Second, children as well as the adults coconstruct the environment in which play takes place. The children do not play in an environment that has been designed for them by adults alone. Third, Lindqvist's pedagogy grounds play in works of children's literature that address epistemological and ethical dilemmas that are of great interest to people in a variety of life stages. Because of this the teacher is personally invested in the topics, and therefore the process and outcomes, of a playworld. The teacher is at least as interested in play as a tool for furthering the children's and his or her own understanding of a topic, such as "fear," as he or she is interested in furthering the student's development. Furthermore, these dilemmas are such that it is the combination of different perspectives, rather than skills or experience that come with age, which produces solutions (e.g. What is real?, What to do if someone you love is doing something harmful to themselves and others?, What does one do in the face of conflicting options? etc.).

The Swedish playworld has thus far generated several promising, preliminary findings, which we are in the midst of investigating. These include: the possibility that some children have moved from hesitating in play to leading play through their participation in the playworld; that the playworld has deepened the teachers' listening to the children and their "becoming closer to each other as pedagogues but also becoming closer to the children"; that the teachers' relationship to the children has changed in other significant ways because of playing with the children in the playworld: that the teachers, after participating in the playworld, now want to play with rather than document the children; that through the playworld the children's voices are being heard and respected in new ways by their teachers; that the playworld itself could be characterized as "an art form that allows one to let go of time and space"; that the children's play outside of the playworld, after their participation in the playworld, is now more focused on story and plot, more joyful, uses different language than it did before the playworld and moves into different worlds than it did before; that children like when the teachers take part in their play (the children consistently invite teachers to play with them, even at their homes, after participating in the playworld with their teachers, and this did not happen before); and that the teachers learn with the children in new ways, discovering the small things that the children encounter from a new perspective, after their participation in the playworld.

These findings lead us to conclude that Vygotsky's theories of play, imagination and creativity, in the current practice of Lindqvist's creative pedagogy of play, have the potential to radically change the relationships between children and adults in early 
childhood education. In the midst of the reduction of early childhood education to preparation for corporate-run test-taking in childhood, which is the current state of the field/practice in the United States, to the progressive and innovative Educare system of Sweden, an international beacon in the field/practice, playworlds are a break with common early childhood educational practice. For reasons that we believe can be better understood through further study of the role of art and creativity in playworlds ${ }^{7}$, this new form of play could contribute towards upsetting modern western childhood, defined and maintained as it is by a relatively newly refined age consciousness. What this might look like we hope to see as the practice is adopted in more, and more varied, settings ${ }^{8}$.

\section{Notas}

${ }^{1}$ Here Vygotsky is referring to Piaget's use of the term "autistic" in Piaget's earlier work. Piaget does not use the word to refer to what is now thought of as the disability of autism, but to refer to a stage of development during which children's thoughts are not directed towards the real world.

${ }^{2}$ It is important to keep in mind that much of this critique was obligatory in the political climate in which Elkonin worked. Because of the constraints imposed on Soviets to dismiss Western authors, some of Elkonin's arguments may have been overstated, or even more significantly altered, in the interest of his professional and personal safely.

${ }^{3}$ Elkonin ends his summary of theoretical research on play with a quote from S. L. Rubinshtein's 1946 response to Vygotsky's 1933 lecture: "In play there is indeed a flight from reality, but there is also a penetration of reality. For this reason there is no escape, no running away from reality to a putative special, make-believe, fictitious, unreal world. The lifeblood of play, everything that it embodies in action, it takes from reality. Play goes beyond the bounds of one situation and abstracts from particular aspects of reality in order to reveal others still more deeply" (1946, p. 592) (2005, p. 93-94).

${ }^{4}$ For a detailed description see Ferholt, 2009, Chapter Three.

${ }^{5} \mathrm{In}$ : Reggio Emilia - influenced preschools the atelier is conceived of as a place of research, invention and exploration, and in Italy it is often constructed in partnership with various professionals, so the translation of "studio" is not entirely accurate.

${ }^{6}$ Lindqvist (1995, p. 210) writes of playworlds: "The more colorful the character which is being dramatized, the more scope for action. Consequently, 
dressing up to play the role is not enough - on the contrary. Giving life to the personality of the character and to the action is crucial to develop a play". And she writes of a specific playworld: "Having played a role such as Fear or Groke, remaining neutral is no longer possible. Moreover, dramatizing and playing roles per se involve an aspect of duality. The "actor" is both teacher and character at the same time, which means that the contours of the individual become distinct in relation to the role which is being played. "Imagine, Groke is really Majilis (the teacher)!”.

${ }^{7}$ This is our intended path for our future playworld research.

8 This is our first time publishing in Brazil. If you are interested in exploring international collaboration in playworlds or related research areas, please contact the authors.

\section{REFERÊNCIAS}

ARIÈS, Phillipe. Centuries of Childhood. New York: Alfred A. Knopf, 1962. BAUMER, S.; FERHOLT, B.; LECUSAY, R. Promoting narrative competence through adult-child joint pretense: Lessons from the Scandinavian educational practice of playworld. The Journal of the Learning Sciences, London, n. 20, p. 576590, 2005.

BROWN, A. Design Experiments: theoretical and methodological challenges in creating complex interventions in classroom settings. The Journal of the Learning Sciences, London, n. 2, v. 2, p. 141-178, 1992.

COBB, P. et al. Design experiments in educational research. Educational Researcher, v. 32, p. 9-13, 2003.

COLE, M.; PELAPRAT, E. "Minding the Gap": imagination, creativity and human cognition. Integrative Psychological and Behavioral Science, v. 45, n. 4, p. 397-418, dic. 2011.

COLLINS, A., JOSEPH, D.; BIELACZYC, K. Design research: theoretical and methodological issues. The Journal of the Learning Sciences, London, v. 13, p. 15-42, 2004 .

ELKONIN, B. D. The psychology of play. Journal of Russian and East European Psychology, v. 43, n. 1, p. 1-98, 2005. 
ENGESTRÖM, Y. The future of activity theory. In: CONGRESS OF THE INTERNATIONAL SOCIETY FOR CULTURAL AND ACTIVITY RESEARCH, 2., San Diego, CA, 2008. Proceedings... San Diego, CA: ISCAR, 2008.

ERIKSON, E. H. Childhood and society. New York: Norton, 1963.

FASS, P. Children of a New World. New York: New York University Press, 2007.

FERHOLT, B. Adult and child development in adult-child joint play: the development of cognition, emotion, imagination and creativity in playworlds. 2009. 278 p. Dissertation (Doctor of Philosophy in Communication) - University of California, San Diego, 2009.

FERHOLT, B. A multiperspectival analysis of creative imagining: applying Vygotsky's method of literary analysis to a playworld. In: CONNERY, C.; JOHNSTEINER AND, V.; MARJANOVIC-SHANE, A. (Ed.) Vygotsky and creativity: a cultural-historical approach to play, meaning-making and the arts. New York: Peter Lang, 2010.

FERHOLT, B. Perezhivanie in researching playworlds: applying the concept of perezhivanie in the study of play. In: Davis, S. et al. (Ed.). Dramatic Interactions inEducation: Vygotskian and Socio-Cultural approaches to drama, education andresearch. London: Bloomsbury. Forthcoming.

FERHOLT, B.; LECUSAY, R. Adult and child development in the zone of proximal development: Socratic dialogue in a layworld. Mind Culture and Activity, San Diego, v. 17, n. 1, p. 59-83, 2010.

FREUD, S. The psychoanalytical treatment of children. New York: Schocken Books, 1964.

FREUD, S. Beyond the pleasure principle. London: Hogarth Press, 1950.

GROOS, K.; BALDWIN, E. L. The play of man. New York: Appleton, 1901. HAKKARAINEN, P. Narrative learning in the fifth dimension. Outlines: critical social studies, Copenhagen, v. 6, n. 1, p. 5-20, 2004.

HAKKARAINEN, P.; FERHOLT, B. Creative imagination in play-worlds: wonderfull early childhood education in Finland and the United States. In: EGAN, K.; CANT, A.; JUDSON, G. (Ed.), Wonder-full education: the centrality of wonder in teaching and learning across the curriculum. New York: Routledge, 2013. 
ILLYENKOV, E. V. The problem of the ideal. Philosophy in the USSR: problems of dialectical materialism, Moscow, 1977.

KLEIN, M. The selected Melanie Klein. New York: The Free Press, 1986.

LEONTIEV, A. N. Problems of the development of the mind. Moscow: Progress Publishers, 1981.

LEWIS, C. S. The lion, the witch and the wardrobe. New York, NY: Macmillan Publishing Co., 1950.

LINDQVIST, G. Från fakta till fantasi. Lund: Studentlitteratur, 1989.

LINDQVIST, G. Ensam i vida världen. Lund: Studentlitteratur, 1992.

LINDQVIST, G. Lekens estetik. En didaktisk studie om lek och kultur i förskolan. Forskningsrapport 95: 12, SKOBA, Högskolan i Karlstad. Stockholm/Sweden: Almqvist \& Wiksell International, 1995. (The Aesthetics of Play. A Didactic Study of Play and Culture in Preschools. Acta Universitatis Upsaliensis. Uppsala studies in Education 62)

LINDQVIST, G. Lekens möjligheter. Lund: Studentlitteratur, 1996.

LINDQVIST, G. Historia som tema och gestaltning. Lund: Studentlitteratur, 2010.

LINDQVIST, G. When small children play: how adults dramatize and children create meaning. Early Years, v. 21, n. 1, p. 7-14, 2001 a.

LINDQVIST, G. The relationship between play and dance. Research in Dance Education, New York, v. 2, n. 1, p. 41-53, 2001 b.

LINDQVIST, G. Lek i skolan. Lund: Studentlitteratur, 2002.

LINDQVIST, G. Vygotsky's theory of creativity. Creativity Research Journal, New York, v. 15, n. 4, p. 245-251, 2003.

MARJANOVIC-SHANE, A. et al. Playworlds: an art of development. In:

LOBMAN, C.; O'NEILL, B. (Ed.), Play and Culture. New York: University Press of America, 2011.

PIAGET, J. Play, dreams, and imitation in childhood. New York: Norton, 1951.

SKOLVERKET. Uppföljning, utvärdering och utveckling i förskolan. Stockholm: Skolverket, 2012.

SUTTON-SMITH, B. The ambiguity of play. Cambridge, MA: Harvard University Press, 1997. 
VYGOTSKY, L. S. The Psychology of Art. Cambridge, MA: M.I.T. Press, 1971.

VYGOTSKY, L. S. Mind in society: the development of higher psychological processes. Cambridge: Harvard University Press, 1978.

VYGOTSKY, L. S. Imagination and its Development in Childhood. In: RIEBER, R. W.; CARTON, A. (Ed.) The collected works of L. S. Vygotsky. New York: Plenum Press, 1987.

VYGOTSKY, L. S. Imagination and creativity in childhood. Journal of Russian and East European Psychology, Moscow, v. 42, n. 1, p. 7-97, 2004.

WINNICOTT, D. W. Playing and reality. New York: Basic Books, 1971.

WOLFF, L. When I imagine a child: the idea of childhood and the philosophy of memory in the enlightenment. Eighteenth Century Studies, Baltimore, v. 31, p. 377 401, 1998. 
A teoria da brincadeira de Vygotsky, imaginação, criatividade na prática atual: a "pedagogia criativa da brincadeira" de Gunilla Lindqvist em jardins de infância nos Estados Unidos e pré-escolas suecas inspiradas no modelo de Reggio Emilia

\section{Resumo}

O ideal de infância ocidental moderna, com sua ênfase na inocência e maleabilidade das crianças, combinou com várias condiçóes sociais para promover a direção do adulto na brincadeira infantil para alcançar metas de desenvolvimento determinadas pelos adultos e, ao mesmo tempo, a proteção pelos adultos de sua influência nas brincadeiras das crianças. No entanto, novas formas de brincadeiras, na qual adultos entram ativamente para o jogo de faz de conta das crianças como um meio de promover o desenvolvimento e a qualidade de vida tanto dos adultos como das crianças, surgiram recentemente em vários países (Suécia, Sérvia - ex-Iugoslávia -, Finlândia, Japão e Estados Unidos). Neste artigo, discute-se o suporte teórico para essa nova forma de atividade. Defende-se que a reinterpretação da teoria de Vygotsky sobre a brincadeira realizada por Gunilla Lindqvist, com sua ênfase na qualidade criativa da brincadeira, é única entre as teorias contemporâneas sobre o brincar da Europa ocidental e dos Estados Unidos. Descreve-se uma série de intervenções formativas que são ao mesmo tempo instâncias dessa nova forma de atividade e uma investigação de seu suporte teórico, que vem sendo realizada nos Estados Unidos e na Suécia. Pesquisadores do
La teoría del juego de Vygotsky, imaginación, creatividad en la practica actual: la "pedagogía creativa del juego" de Gunilla Lindquist en jardines de infancia en los Estados Unidos y escuelas infantiles suecas inspiradas en el modelo de Reggio Emilia

\section{Resumen}

El ideal de la infancia occidental moderna, con su énfasis en la inocencia y la maleabilidad de los niños, se ha combinado con diferentes condiciones sociales para promover la dirección del adulto sobre el juego de los nińos hacia objetivos de desarrollo determinados por el adulto y, al mismo tiempo, la protección por los adultos de su influencia sobre el juego de los nińos. Sin embargo, las nuevas formas de juego, en las que los adultos entran activamente en el juego de fantasía de los nińos pequeños como medio de promover el desarrollo y la calidad de vida de ambos niños $\mathrm{y}$ adultos, surgieron recientemente en varios países (Suecia, Serbia (la ex Yugoslavia), Finlandia, Japón y Estados Unidos). En este trabajo se discute el soporte teórico de esta nueva forma de actividad: sostenemos que la reinterpretación de Gunilla Lindqvist de la teoría del juego de Vygotsky, con su énfasis en la calidad creativa del juego, es única entre las teorías europeas occidentales y americanas contemporáneas sobre juego. Se describe una serie de intervenciones formativas que son al mismo tiempo instancias de esta nueva forma de actividad y una investigación de su soporte teórico, que se llevan a cabo en los Estados Unidos y Suecia. Investigadores del 
Laboratório de Cognição Humana Comparada da Universidade da Califórnia, em San Diego, têm implementado e estudado a pedagogia criativa da brincadeira de Lindqvist em turmas de primeira infância de escolas públicas nos Estados Unidos. Durante o ano passado o componente central dessa pedagogia, mundos de faz de conta, foi introduzido e estudado em três pré-escolas suecas inspiradas em Reggio Emilia. Em conclusão, alguns dos resultados desses projetos de pesquisa sã̃o apresentados.

Palavras-Chave: Teoria Sócio-HistóricoCultural. Brincadeira. Educação Infantil.
Laboratorio de Cognición Humana Comparada en la Universidad de California en San Diego han implementado y estudiado la pedagogía creativa del juego de Lindqvist en los Estados Unidos en aulas de las escuelas públicas para la primera infancia. Durante el año pasado, el componente central de esta pedagogía, mundos de juego, se ha introducido y estudiado en tres centros preescolares suecos inspirados en ReggioEmilia. En conclusión, algunos de los resultados de estos proyectos de investigación se presentan.

Palabras claves: Teoría histórico-cultural. Juego. Educación infantil.

\title{
Monica Nilsson
}

E-mail: monica.nilsson@hlk.hj.se

\section{Beth Ferholt}

E-mail:bferholt@brooklyn.cuny.edu

\author{
Recebido em: 5/5/2014 \\ Aprovado em: 26/7/2014
}

